Website. http://hilirisasi.lppm.unand.ac.id e-ISSN: 2621-7198

\title{
PENERAPAN TEKNOLOGI SILASE JERAMI JAGUNG SEBAGAI PAKAN TERNAK DI OPHIR NAGARI KOTO BARU KABUPATEN PASAMAN BARAT
}

\author{
Ferry Lismanto Syaiful *) dan Yayuk Sri Utami \\ Fakultas Peternakan Universitas Andalas
}

Email: ferrylismanto@ansci.unand.ac.id

\begin{abstract}
ABSTRAK
Pakan merupakan suatu kebutuhan yang mutlak harus diperhatikan dalam pemeliharaan ternak. Umumnya di musim kemarau, peternak terkendala dalam ketersediaan pakan sulit didapatkan. Disisi lain, Pada saat musim panen jagung di Jorong Ophir Nagari Koto Baru Kabupaten Pasaman Barat ketersediaan jerami jagung sangat melimpah. Jerami jagung sangat berpotensi sebagai sumber pakan, namun pemanfaatannya belum optimal dikarenakan kualitasnya masih rendah. Untuk peningkatan kualitas dan manfaat jerami jagung ini maka diperlukan petani sebuah teknologi yang mudah dan sederhana untuk peningkatan kualitas pakan diantaranya teknologi silase jerami jagung. Tujuan kegiatan ini yaitu untuk peningkatan pengetahuan dan keterampilan peternak dan petani atau masyarakat Jorong Ophir Nagari Koto Baru dalam penerapan teknologi pembuatan silase jerami jagung sebagai pakan ternak. Kegiatan pelatihan dilakukan Jorong Ophir yang melibatkan petani peternak dan masyarakat. Metode kegiatan berupa penyuluhan, pelatihan dan evaluasi. Pada kegiatan ini terlihat peserta antusias mengikuti pelaksanaan kegiatan. Setelah pelaksanaan kegiatan ini terlihat adanya peningkatan pengetahuan dan pemahaman masyarakat dalam penerapan pembuatan silase jerami jagung sebagai pengolahan pakan ternak. Hal ini tentunya peternak dapat mengotimalisasi limbah sebagai pakan ternak yang harga yang relatif murah. Berharap dari kegiatan ini adanya keberlanjutan program yang dilakukan peternak agar optimalisasi pakan yang berkualitas untuk peningkatan produktivitas ternak.
\end{abstract}

Kata Kunci: silase, jerami jagung, pakan ternak

\section{Application of Corn Straw Silage Technology as Livestock Feed in Ophir Nagari Koto Baru West Pasaman District}

\begin{abstract}
Feed is an absolute necessity that must be considered in raising livestock. Generally, in the dry season, farmers are constrained by the availability of challenging to obtain feed. On the other hand, during the corn harvest season in Jorong Ophir Nagari Koto Baru, West Pasaman Regency, the availability of corn straw is very abundant. Corn straw is very potential as a feed source, but its utilization is not optimal because its quality is still low. To improve the quality and benefits of corn straw, farmers need an easy and simple technology to improve feed quality, including corn straw silage technology. This activity aims to increase the knowledge and skills of breeders and farmers or the people of Jorong Ophir Nagari Koto Baru in the application of technology for making corn straw silage as animal feed. The training activities were carried out by Jorong Ophir, which involved farmers and the community. The method of activity is counseling, training, and evaluation. In this activity, participants were seen enthusiastically following the implementation of the activity. After implementing this activity, it was seen that there was an increase in community knowledge and understanding in the application of making corn straw silage as animal feed processing. Of course, farmers can optimize waste as relatively cheap animal feed. We hope that from this activity, there will be a sustainability program carried out by farmers to optimize quality feed for increasing livestock productivity.
\end{abstract}

Keywords: silage, corn straw, animal feed 


\section{PENDAHULUAN}

Pada saat musim panen jagung di Jorong Ophir Kabupaten Pasaman Barat ketersediaan jerami jagung sangat melimpah, begitu selesai masa panen jagung maka limbah dari pemanenan dibiarkan saja atau dibakar. Padahal jerami jagung dapat dimanfaatkan menjadi pakan dari ternak karena masyarakat di jorong Ophir juga banyak beternak sapi bali. Karena itu teknologi pengolahan pengawetan jerami jagung perlu dibudidayakan oleh petani ternak guna tersedianya hijauan pakan ternak sepanjang tahun. Oleh karena itu penulis melakukan kegiatan pelatihan pembuatan silase jerami jagung guna untuk meningkatkan kemampuan dan keterampilan masyarakat untuk mengolah jerami jagung yang terbengkalai dan dimanfaatkan untuk pakan ternak.

Jerami jagung dimanfaatkan sebagai hijauan pakan ternak yang sudah banyak dilakukan petani, namun pemanfaatannya belum optimal. Selain diberikan pada ternak sebagai hijauan segar, jerami jagung juga dapat diberikan dalam bentuk pakan hijauan ternak yang telah dilakukan proses pengolahan dengan teknologi pengolahan pakan seperti dalam bentuk pengolahan silase.

Silase merupakan olahan atau pengolahan yang dilakukan pada pakan ternak dengan proses fermentasi hijauan pakan dengan kandungan air yang tinggi.bahan baku yang digunakan berupa tanaman hijauan, limbah industri pertanian, serta bahan pakan alami lainnya.

Seiring perkembangannya sentra pertanian/ perkebunan jagung di daerah Jorong Ophir yang jua bisa memenuhi kebutuhan peternakan sehingga dapat dikembangkan dan dapat membantu petani dan peternak dalam menaikkan taraf hidupnya.

Jerami jagung merupakan sisa dari tanaman jagung setelah buahnya dipanen dikurangi akar dan sebagian batang yang tersisa dan dapat diberikan kepada ternak, baik dalam bentuk segar maupun kering. Pemanfaatan jerami jagung adalah sebagai makanan ternak ruminansia seperti sapi, kerbau, kambing dan domba Nilai nutrisi dari hasil samping tanaman jagung sangat bervariasi, kulit jagung mempunyai nilai kecernaan bahan kering in vitro yang tertinggi (68\%) sedangkan batang jagung merupakan bahan yang paling sulit untuk dicerna dalam rumen (51\%). Nilai kecernaan kulit jagung dan tongkol (60\%) ini hampir sama dengan nilai kecernaan rumput Gajah sehingga kedua bahan ini dapat menggantikan rumput gajah sebagai sumber hijauan (McCutcheon dan Samples, 2002).

Banyaknya petani jagung di Ophir sehingga banyak pula limbah jerami jagung yang tersedia namun dikarenakan masyarakat tidak mengetahui cara pengolahan dari limbah ini sehingga limbah tersebut dihilangkan dengan membakarnya. Tindakan ini dapat menyebabkan kerusakan lingkungan. Jerami jagung dapat digunakan sebagai pakan ternak ketika ketersediaan pakan hijauan tidak terpenuhi, produksi jerami jagung mencapai 86,62 ton/ha/tahun (Suyitman dkk., 2012). Nilai nutrisi dan limbah tanaman dan hasil sampingan tanaman jagung sangat bervariasi. Kulit jagung mempunyai nilai kecernaan bahan kering in vitro yang tinggi (68\%) sedangkan batang jagung merupakan bahan yang paling sulit untuk dicerna dalam rumen (51\%).

Sutardi (2009) menyatakan bahwa kandungan zat makanan yang ada pada jerami jagung sebagai berikut, komposisi zat makanan jerami jagung yaitu: Serat Kasar 27,70 (\%),Abu 10,20 (\%), BETN 50,20 (\%), TDN54,08. 
Website. http://hilirisasi.lppm.unand.ac.id e-ISSN: 2621-7198

Silase adalah salah satu teknik pengawetan pakan atau hijauan pada kadar air tertentu melalui proses fermentasi mikrobial oleh bakteri asam laktat yang disebut ensilase dan berlangsung di dalam tempat yang disebut silo. Silase sudah diterapkan dibanyak negara khususnya negara beriklim sub tropis, dimana musim menjadi kendala utama ketersediaan hijauan dan penerapan pengawetan dengan metode pengeringan sulit dilakukan (Saun dan Heinrichs, 2008).

Perry et al. (2003) melaporkan bahwa dalam pembuatan silase harus mengandung kadar air $60-75 \%$, teknologi ini melalui proses ensilase yang akan menghasilkan produk silase. Lebih lanjut Bolsen dan Sapienza (1993) menambahkan bahwa tujuan pembuatan silase adalah sebagai salah satu alternatif untuk mengawetkan pakan segar sehingga kandungan nutrisi yang ada di dalam pakan tersebut tidak hilang atau dapat dipertahankan, sehingga pembuatannya tidak tergantung musim.

Fermentasi yaitu proses perombakan struktur keras secara fisik, kimia dan biologi, merombak bahan dari struktur yang komplek menjadi sederhana, sehingga daya cerna ternak menjadi lebih efisien. Pada saat ini telah banyak dipasarkan berbagai produk starter fermentasi yang digunakan untuk pengolahan pakan ternak. Mikroba yang digunakan sebagai starter fermentasi dapat berupa satu macam mikroba ataupun kelompok mikroba yang bekerja secara sinergis. Probiotik merupakan salah satu produk starter fermentasi yang mengandung kelompok mikroba sinergis diantaranya adalah starbio dan probiofeed. Fermentasi merupakan salah satu teknologi bahan makanan secara biologis yang melibatkan aktivitas mikroorganisme guna memperbaiki gizi bahan berkualitas rendah. Fermentasi dapat meningkatkan kualitas bahan pakan, karena pada proses fermentasi terjadi perubahan kimiawi senyawa-senyawa organik (karbohidrat, lemak, protein, serat kasar dan bahan lainnya) baik dalam keadaan aerob maupun anaerob, melalui kerja enzim yang dihasilkan mikroba (Sukaryana dkk., 2011).

Ciri-ciri fermentasi silase yang kurang baik yaitu tingginya asam butirat, $\mathrm{pH}$, kadar amonia, sedangkan ciri-ciri fermentasi yang sempurna yaitu $\mathrm{pH}$ turun dengan cepat, tidak adanya bakteri clostrodia dan kadar amonia rendah. Selain itu, kualitas silase yang baik memiliki kandungan bahan kering antara 35\% - 40\% dan cukup mengandung gula $>2 \%$ bahan segar (Ohmomo et al., 2002).

Kualitas silase dicapai ketika asam laktat sebagai asam yang dominan di produksi, menunjukkan fermentasi asam yang efisien ketika penurunan $\mathrm{pH}$ silase terjadi dengan cepat (Harahap, 2009). Setelah dilihat potensi Jorong Ophir maka penulis melakukan kegiatan pelatihan pembuatan silase dengan tujuan meningkatkan pengetahuan dan keterampilan masyarakat terkait pembuatan silase jerami jagung.

\section{METODOLOGI}

Kegiatan dilaksanakan di Jorong Ophir, Nagari Koto Baru. Adapun kegiatan ini dilakukan dengan mengadakan pelatihan pembuatan silase jerami jagung dengan topik pembahasan dalam penyampaian ke masyarakatnya terbagi dua tahapan yaitu pengenalan tentang apa itu silase dan apa manfaat atau kandungan jerami jagung untuk ternak sapi. Yang kedua penjelasan tahapan pembuatan silase jerami jagung. Adapun sasaran dari kegiatan ini yaitu para peternak dan petani atau masyarakat Jorong Ophir, Nagari Koto Baru. 
Pada saat pelatihan alat yang digunakan yaitu parang atau chopper yang digunakan untuk mencacah jerami jagung, kantung plastik sebagai wadah untuk fermentasi silase jagung, karung/plastik berguna untuk alas dalam pencampuran bahanbahan silase. Bahan yang digunakan dalam pembuatan silase jerami jagung yaitu, $5 \mathrm{Kg}$ jerami jagung, tetes tebu atau molases (1\% dari berat jerami jagung), Dedak atau bekatul ( $3 \%$ dari berat jerami jagung), dekomposer/feses ayam $(0,04 \%$ berat jerami jagung).

Proses pembuatan silase jerami jagung yaitu, jerami jagung di cacah kira-kira $5 \mathrm{~cm}$ panjangnya, setelah di cacah dikeringkan sampai kering udara atau sekedar pelayuan saja, setelah dijemur jerami jagung dan bahan-bahan lainnya dicampur diatas karung setelah merata barulah dimasukkan ke dalam kantong plastik dan diikat rapat sampai tidak ada udara di dalam kantung plastik, lama fermentasi sekitar 2 minggu paling cepat. Sasaran dari kegiatan pelatihan pembuatan silase jerami jagung ini yaitu masyarakat Jorong Ophir khususnya para peternak dan petani. Sehingga dapat meningkatkan keterampilan dari mereka serta meningkatkan taraf hidup masyarakat.

\section{HASIL DAN PEMBAHASAN}

Pada kegiatan ini terdiri atas tiga kegiatan yaitu berupa penyuluhan, pelatihan dan evaluasi. Pada kegiatan ini terlihat peserta antusias mengikuti pelaksanaan kegiatan dengan penjelasan sebagai berikut:

\section{Penyuluhan Silase Jerami Jagung}

Materi yang diberikan pada saat penyuluhan adalah teknik pengolahan pakan dan silase jerami. Pada kegiatan ini peserta dibekali pengetahuan pengolahan pakan berupa ceramah dan diskusi.

Setelah dilakukan penyuluhan terlihat adanya peningkatan pengetahuan peserta dalam materi yang diberikan. Awalnya peserta tidak mengetahui tentang kandungan dan manfaat dari jerami jagung. Namun setelah penyuluhan peserta mulai dapat mengetahui dan memahami tentang pengolahan pakan berasal dari limbah ini.

Disamping itu, peserta juga telah paham mengenai teknik pengolahan pakan yang berasal dari limbah pertanian ini. Hal ini tentunya dapat mengoptimalisasi limbah sebagai bahan pakan ternak.

Salah satu teknik pengawetan pakan atau hijauan pada kadar air tertentu melalui proses fermentasi mikrobial oleh bakteri asam laktat yang disebut ensilase dan berlangsung di dalam tempat yang disebut silo. Proses teknik pengawetan pakan ini juga dikenal dengan silase.

Silase sudah diterapkan di banyak negara khususnya negara beriklim sub tropis, dimana musim menjadi kendala utama ketersediaan hijauan dan penerapan pengawetan dengan metode pengeringan sulit dilakukan (Saun dan Heinrichs, 2008).

Jerami jagung dapat digunakan sebagai pakan ternak ketika ketersediaan pakan hijauan tidak terpenuhi, produksi jerami jagung mencapai 86,62 ton/ha/tahun (Suyitman dkk., 2012). Nilai nutrisi dan limbah tanaman dan hasil sampingan tanaman jagung sangat bervariasi. Kulit jagung mempunyai nilai kecernaan bahan kering in vitro yang tinggi (68\%) sedangkan batang jagung merupakan bahan yang paling sulit untuk dicerna dalam rumen $(51 \%)$. 


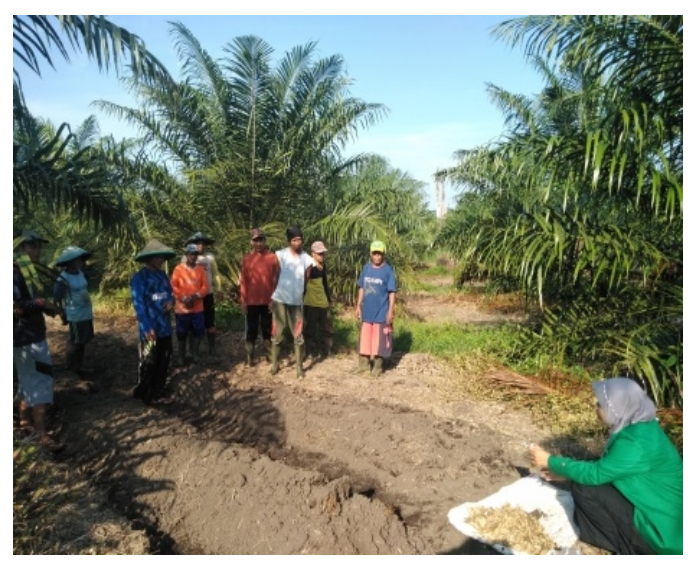

Gambar 1. Penyuluhan Silase Jerami Jagung

\section{Pelatihan Pembuatan Silase Jerami Jagung}

Pelatihan pembuatan silase jagung ini dilakukan dengan praktek langsung ke peserta. Hal ini dilakukan untuk penanggulangan limbah jagung yang berlimpah di daerah ini. Disamping itu optimalisasi limbah jagung ini dapat digunakan sebagai pakan ternak.

Jerami jagung merupakan limbah pertanian yang sangat berpotensi besar dijadikan sumber pakan, namun ini kualitasnya masih rendah. Untuk peningkatan kualitas pakan maka perlu ditingkatkan melalui silase.

Pelatihan pembuatan silase jerami jagung diberikan agar petani dan peternak dapat menanggulangi limbah jagung yang melimpah dan dapat memenuhi kebutuhan nutrisi dari ternak sapi. Disamping itu dapat meningkatkan pengetahuan dan keterampilan peternak atau masyarakat tentang silase jerami jagung.

Sebelum kegiatan petani dan peternak masih banyak yang tidak mengetahui dari pengolahan pakan ternak dari jerami jagung. Namun setelah dilakukan pelatihan terlihat adanya peningkatan pengetahuan dan pemahaman mereka dalam manfaat dan cara pengolahan silase jerami jagung sebagai pakan ternak. Disamping itu juga dapat menambah kemampuan dan pengetahuan masyarakat sehingga dengan ini masyarakat dapat meningkatkan kualitas pakan dari ternaknya yang berdampak kepada peningkatan kualitas hidup masyarakat Jorong Ophir. 


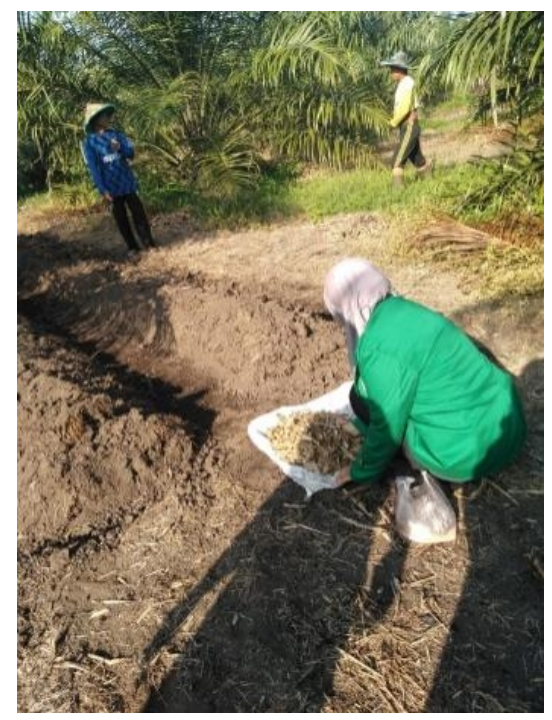

Gambar 2. Silase Jerami Jagung

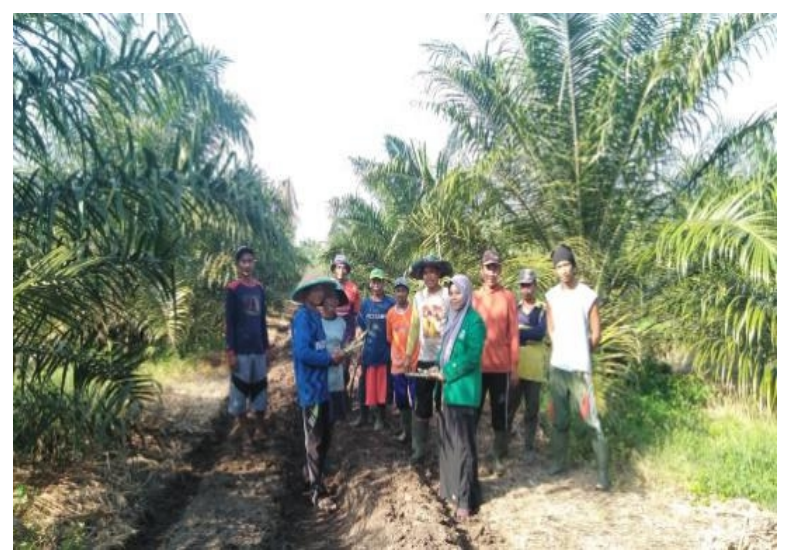

Gambar 3. Foto Kegiatan Pelatihan Pembuatan Silase Jerami Jagung

\section{KESIMPULAN DAN SARAN}

Setelah pelaksanaan kegiatan ini terlihat adanya peningkatan pengetahuan dan pemahaman masyarakat dalam penerapan pembuatan silase jerami jagung sebagai pengolahan pakan ternak. Hal ini tentunya dapat mengotimalisasi limbah sebagai pakan ternak yang harga yang relatif murah.

Berharap dari kegiatan ini adanya keberlanjutan program yang dilakukan peternak agar optimalisasi pakan yang berkualitas untuk peningkatan produktivitas ternak. 


\section{UCAPAN TERIMAKASIH}

Ucapan terima kasih disampaikan kepada Bapak Wali Nagari dan aparatur Nagari Koto Baru dan Nagari-nagari persiapan serta Masyarakat Jorong Ophir Nagari Koto Baru yang telah menyukseskan pelaksanaan kegiatan ini.

\section{DAFTAR PUSTAKA}

Jamarun. 1991. Teknologi Pengawetan Pakan Ternak. USU Repository, Medan.

Murni, R., Suparjo, Akmal, dan B. L. Ginting. 2008. Metode Pengolahan Limbah Untuk Pakan Ternak. Universitas Jambi, Jambi

Mccutcheon, P and Samples, T. 2002. Textbook of Feed Processing Technology. Vikas Publishing House. New Delhi.

Saun Henric. 2008. Animal Nutrition. Oxford \& IBM Pub. Co Calcuta

Suyitman. 2012. Pemanfaatan Limbah Sebagai Bahan Pakan Ternak. PT. Gramedia Pustaka Utama, Jakarta

Sutardi, T. 2009. Landasan Ilmu Nutrisi. Jilid 1. Fakultas Peternakan Institut Pertanian Bogor, Bogor.

Syaiful F.L, D.T. Diva dan M. Hafizoh. 2020. Penerapan teknologi amoniasi jerami sebagai pakan alternatif sapi potong di Kenagarian Sungai Kunyit, Solok Selatan. Jurnal Hilirisasi IPTEKS, Vol. 3 No. 1, Maret 2020.

Syaiful F.L, dan F. Agustin. 2019. Diseminasi teknologi pakan komplit berbasis bahan baku lokal pada sapi potong di daerah Kinali Pasaman Barat. Jurnal Hilirisasi IPTEKS, 2(1): Maret 2019

Syaiful.F.L., Suyitman, Evitayani, Khasrad dan Endang Purwati. 2019. Pengembangan budidaya rumput unggul menggunakan fungi mikoriza arbuskula sebagai pakan sapi potong di Parak Karakah Kota Padang. Jurnal Hilirisasi IPTEKS, 2(3a); September 2019

Syaiful F.L, F. Agustin, Rusmana, U.G.S. Dinata dan Efrizal. 2018. Pengembangan sapi potong melalui penerapan teknologi deteksi kebuntingan dini dan inovasi pakan ramah lingkungan pada kelompok tani di Langgam, Pasaman Barat. Jurnal Hilirisasi IPTEKS. 1 (4): 191-202.

Syaiful F.L. 2018. Diseminasi teknologi deteksi kebuntingan dini "DEEA GestDect" terhadap sapi potong di Kinali Kabupaten Pasaman Barat. Jurnal Hilirisasi IPTEKS. 1(3): 17-25 
Syaiful. F.L., U.G.S. Dinata dan Ferido. 2018. Pemberdayaan masyarakat Nagari Sontang Kabupaten Pasaman melalui inovasi budidaya sapi potong dan inovasi pakan alternatif yang ramah lingkungan. Buletin Ilmiah Nagari Membangun. 1(3): 21-31

Syaiful. F.L., U.G.S. Dinata dan Y. Hidayattullah. 2018. Pemberdayaan masyarakat melalui pemanfaatan limbah sekam padi sebagai bahan bakar kompor sekam yang ramah lingkungan di Kinali, Pasaman Barat. Buletin Ilmiah Nagari Membangun. 1(3): 62-69

Syaiful, F.L. 2018. Pemberdayaan masyarakat melalui budidaya sapi potong terintegrasi sawit dan penanaman rumput gajah sebagai bahan pakan ternak di nagari Kinali Kabupaten Pasaman Barat. Unes Journal of Community Service. 2(2): 142-149.

Syaiful, F.L. 2018. Optimalisasi inseminasi buatan sapi potong melalui akurasi kebuntingan dini terhadap uji punyakoti dan palpasi rektal. Jurnal Embrio. 10(2): 41-48. 